\title{
PENINGKATAN HASIL BELAJAR IPS MELALUI MODEL CONTEXTUAL TEACHING AND LEARNING PADA SISWA KELAS IV SD 2 BACIN KUDUSTAHUN 2013/2014
}

\author{
Mirnawati, Mohammad Kanzunnudin, Ika Oktavianti \\ Progdi Pendidikan Guru Sekolah Dasar FKIP Universitas Muria Kudus \\ Email: Mirnadciezt@yahoo.co.id, Ioktavianti@ymail.com
}

\begin{abstract}
The purpose of this research are: (1) to explain the CTL implementation in increasing the result of studying Social Studies $4^{\text {th }}$ grade students Elementary School 2 Bacin (2) to describe increasing the result of studying Social Studies material natural resources through by applicating CTL model on $4^{\text {th }}$ grade students Elementary School 2 Bacin.

The research method used Classroom Action Research (CAR) with two cycles CTL implement learning models using model design CAR by Stephen Kemmis and Robin Mc Taggart with CAR steps: (1) planning, (2) implementation of the action, (3) observation and (4) reflection. Mechanical analysis of qualitative and quantitative data. Instruments of data collection used in the form of observation, tests, field notes and documentation.

The results of first cycle showed teaching management activities completeness of $71.5 \%$ with the criteria of "good" and the second cycle increased to $92.5 \%$ with the criteria of "very good". Social Studies's students learning outcomes cognitive $72.22 \%$ in the first cycle and the second cycle increased up to 94.44\%. Social Studies's students affective learning outcomes in the first cycle up to $72.93 \%$ percentage with the criteria of "good" and the second cycle increased to $85.38 \%$ with the criteria of "very good". Psychomotor domains of learning outcomes Social Studies students first cycle was $71.5 \%$ with the criteria of "very good" and the second cycle increased up to $86.1 \%$ with the criteria of "very good".

The conclusions in this study by using the CTL learning model to improve learning outcomes of Social Studies students both the cognitive, affective and psychomotor fourth grade students of Elementary School 2 Bacin Kudus year 2013/2014. In any learning process is can increase student learning outcomes. Students should be active in learning, collaboration among students in the group. It is expected that future researchers are expected to be used as a reference by applying learning model CTL in the broader material and different grade levels.
\end{abstract}

\footnotetext{
ABSTRAK

Tujuan dilaksanakan penelitian ini ialah (1) untuk menjelaskan implementasi model CTL dalam meningkatkan hasil belajar IPS siswa kelas IV SD 2 Bacin, dan (2) untuk menjelaskan peningkatan hasil belajar IPS siswa dengan diterapkannya model CTL pada siswa kelas IV SD 2 Bacin.
} 
Metode penelitian yang digunakan yaitu Penelitian Tindakan Kelas (PTK) dengan dua siklus yang menerapkan model CTL dengan menggunakan desain model PTK Stephen Kemmis dan Robin Mc Taggart dengan langkah PTK: (1) perencanaan, (2) pelaksanaan tindakan, (3) observasi dan (4) refleksi. Teknik analisis data kualitatif dan kuantitatif. Instrumen pengumpulan data yang digunakan berupa observasi, tes, catatan lapangan dan dokumentasi.

Hasil penelitian siklus I pengelolaan pembelajaran guru mencapai persentase ketuntasan 71,5\% dengan kriteria "baik" dan mengalami peningkatan siklus II menjadi 92,5\% dengan kriteria "sangat baik". Hasil belajar IPS siswa ranah kognitif pada siklus I $72,22 \%$ dan pada siklus II meningkat menjadi $94,44 \%$. Hasil belajar IPS ranah afektif siswa siklus I mencapai persentase $72,93 \%$ dengan kriteria "baik" dan siklus II meningkat menjadi 85,38\% dengan kriteria "sangat baik". Hasil belajar IPS ranah psikomotorik siswa siklus I 71,5\% dengan kriteria "sangat baik" dan siklus II meningkat menjadi 86,1\% dengan kriteria "sangat baik".

Simpulan pada penelitian ini yakni dengan menggunakan model CTL dapat meningkatkan hasil belajar IPS siswa baik dari ranah kognitif, afektif maupun psikomotorik siswa kelas IV SD 2 Bacin Kudus tahun 2013/2014. Dalam setiap proses. Siswa hendaknya aktif dalam pembelajaran dan kerjasama diantara siswa dalam kelompok perlu. Diharapkan peneliti yang akan datang diharapkan dapat dijadikan referensi dengan menerapkan model CTL dengan topik pelestarian sumber daya alam dengan materi yang lebih luas.

\section{PENDAHULUAN}

Salah satu faktor yang ikut serta menentukan kemajuan bangsa ke arah yang lebih baik yaitu pendidikan. Dalam pasal 1 ayat $1 \mathrm{UU}$ Sisdiknas No. 20 Tahun 2003 disebutkan bahwa pendidikan adalah usaha sadar dan terencana untuk mewujudkan suasana belajar dan proses pembelajaran agar peserta didik secara aktif mengembangkan potensi dirinya untuk memiliki kekuatan spiritual keagamaan, pengendalian diri, kepribadian, kecerdasan, akhlak mulia serta keterampilan yang diperlukan dirinya, masyarakat, bangsa dan negara.

Berpijak Undang-Undang diatas, pendidikan memegang fungsi yang sangat penting. Guna mencapai tujuan tersebut, maka perlu adanya perubahan paradigma pembelajaran. Selama proses pembelajaran guru menjadi pemeran utama dalam menciptakan situasi interaktif yang edukatif, yakni interaksi antara guru dengan siswa, siswa dengan siswa dan sumber pembelajaran yang menunjang tercapainya tujuan belajar. Oleh sebab itu, guru harus selalu kreatif dan inovatif dalam melakukan pembelajaran, selain itu guru juga harus mampu membuat mata pelajaran yang dianggap siswa membosankan menjadi pelajaran yang menarik dan menyenangkan supaya siswa lebih mudah mengerti dan memahami materi yang disampaikan dan juga siswa antusias mengikuti pembelajaran, sehingga 
pembelajaran yang dilaksanakan dapat berkualitas dan dapat meningkatkan prestasi belajar siswa khususnya pada mata pelajaran IPS di Sekolah Dasar.

Somantri (dalam Sapriya, 2009: 11) pendidikan IPS adalah penyederhanaan atau adaptasi dari disiplin ilmu-ilmu sosial dan humaniora, serta kegiatan dasar manusia yang diorganisasikan dan disajikan secara ilmiah dan pedagogis/psikologis untuk tujuan pendidikan. Dalam kurikulum IPS ialah mata pelajaran yang mempelajari berbagai kenyataan sosial dalam kehidupan sehari-hari yang bersumber dari geografi, ekonomi, sejarah, antropologi, sosiologi, dan tata negara. IPS sebagai salah satu bidang studi yang memiliki tujuan membekali siswa untuk mengembangkan penalaran di samping aspek nilai dan moral. Implementasinya, materi IPS hanya menekankan aspek pengetahuan yang berpusat pada guru dan hanya membentuk budaya menghafal, sehingga pengetahuan dan informasi yang diterima siswa sebatas produk hafalan. Pembelajaran IPS sangat menjenuhkan karena penyajiannya kurang menarik, bersifat monoton dan konvensional, hanya sekedar ceramah.

Bertumpu pada hasil observasi di lapangan yang peneliti lakukan pada tanggal 3 Agustus 2013, diperoleh minimnya hasil belajar rata-rata dihadapi oleh sejumlah siswa yang tidak memiliki dorongan belajar. Sehingga nilai rata-rata mata pelajaran IPS di SD 2 Bacin Kudus sangat rendah yaitu mencapai 58,3. Hal ini disebabkan karena guru dalam proses pembelajaran hanya menggunakan metode ceramah, tanpa menggunakan alat peraga dan materi pelajaran tidak disampaikan secara efektif. Siswa juga sulit memahami materi sumber daya alam yang hanya dijelaskan secara abstrak.

Problematika yang ada ini harus segera diatasi. Salah satu model yang dipandang tepat untuk mengatasi problematika tersebut dan mampu meningkatkan hasil belajar ialah model CTL. Daryanto (2012: 153) Contextual Teaching and Learning (CTL) merupakan konsep belajar yang membantu guru mengkaitkan antara materi yang diajarkan dengan situasi dunia nyata siswa dan mendorong siswa membuat hubungan antara pengetahuan yang dimilikinya dengan penerapannya dalam kehidupan mereka sebagai anggota keluarga dan masyarakat. Adapun komponen pokok model CTL yaitu konstruktivisme (constructivism), inkuiri (inquiry), bertanya (questioning), masyarakat belajar (learning community), pemodelan (modelling), refleksi (reflection) dan penilaian nyata (authentic assesment) Hasil penelitian yang memperkuat peneliti untuk melakukan penelitian tindakan dengan menerapkan model CTL adalah penelitian Yaningsih (2010) terhadap siswa kelas IV SD Negeri 02 Papahan yang berjumlah 33 siswa. Hasil analisis datanya yaitu: (1) penerapan pendakatan Contextual Teaching and Learning (CTL) dalam pembelajaran IPS pada pokok bahasan kenampakan alam dapat berpengaruh langsung terhadap peningkatan motivasi belajar siswa menunjukkan hasil penelitian yaitu 
siklus I, rata-rata 69,55. Hasil belajar siswa pada akhir siklus II menunjukkan perolehan, rata-rata 76,73. Siswa yang mencapai ketuntasan (KKM) pada hasil tes awal (pretest) sebanyak 8 siswa $(24,24 \%)$, pada siklus I menjadi 16 siswa $(48,48 \%)$, pada siklus II mengalami peningkatan menjadi 30 siswa $(90,90 \%)$.

Tujuan penelitian ini adalah menjelaskan implementasi model Contextual Teaching and Learning (CTL) dalam meningkatkan hasil belajar IPS materi Sumber Daya Alam pada siswa kelas IV Semester I SD 2 Bacin Kecamatan Bae Kabupaten Kudus tahun ajaran 2013/2014 dan menjelaskan peningkatan hasil belajar siswa pada mata pelajaran IPS materi Sumber Daya Alam dengan diterapkannya model Contextual Teaching and Learning (CTL) pada siswa kelas IV Semester 1 SD 2 Bacin Kecamatan Bae Kabupaten Kudus tahun ajaran 2013/2014.

\section{METODE PENELITIAN}

Pelaksanaan penelitian tindakan kelas (PTK) dimulai dari pengajuan judul bulan Juli 2013, penyusunan proposal bulan Agustus
2013. Penelitian tindakan kelas (PTK) mulai dari pelaksanaan siklus I sampai siklus II dilaksanakan pada bulan Oktober sampai November 2013 semester 1 tahun ajaran 2013/2014. Model pembelajaran penelitian tindakan kelas ini berpedoman pada model pembelajaran Kemmis yang dikembangkan oleh Stephen Kemmis dan Robin Mc Taggart tahun 1988 (dalam Arikunto, 2010: 137). Mereka menggunakan empat komponen penelitian (perencanaan, tindakan, observasi, dan refleksi) dalam suatu sistem spiral yang saling terkait. Antara langkah satu dengan langkah berikutnya saling terkait. PTK ini dilaksanakan melalui dua siklus, yaitu proses tindakan pada siklus I dan proses pada siklus II. Siklus I untuk mengukur kemampuan awal siswa, sedangkan siklus II digunakan untuk memperkuat siklus I sekaligus sebagai refleksi pada siklus I dan siklus II. Tahapan yang dilakukan dalam penelitian tindakan kelas ini yaitu sebagai berikut.

Skema Tahapan Penelitian Tindakan Kelas

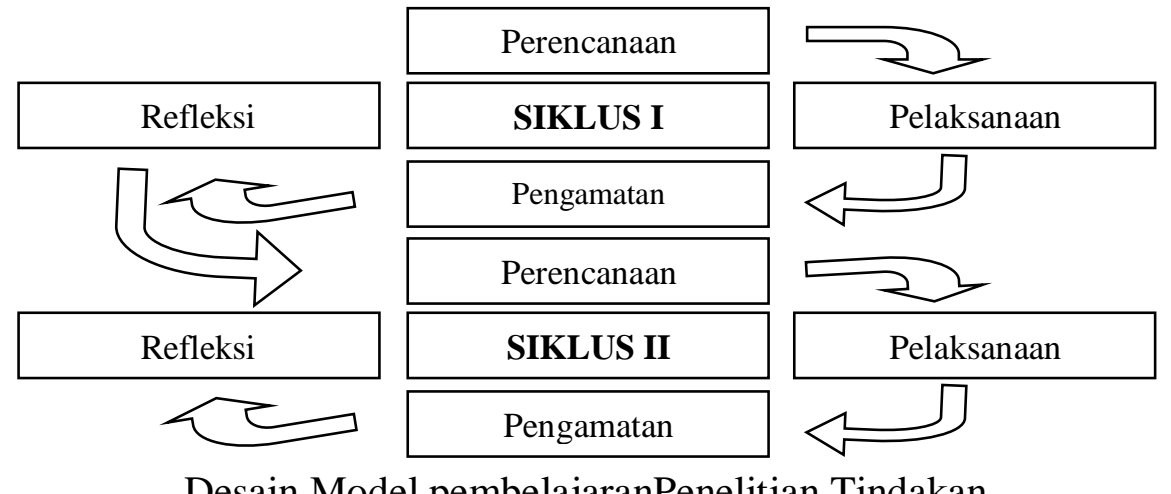

Desain Model pembelajaranPenelitian Tindakan

Kelas Stephen Kemmis dan Robin Mc Taggart (Arikunto, 2010: 137) 
Metode pengumpulan data yang digunakan dalam penelitian tindakan kelas dilakukan dengan (1) observasi, (2) wawancara, (3) tes, (4) dokumentasi, dan (5) catatan lapangan. Teknik analisis data yang digunakan yaitu teknik analisis data kualitatif dan kuantitatif.

\section{HASIL PENELITIAN}

Pelaksanaan penelitian dilakukan selama 2 siklus. Siklus I terdiri atas 2 kali pertemuan dan siklus II juga terdiri dari 2 kali pertemuan, berarti peneliti melakukan 4 kali pertemuan yang terorganisir dalam 2 siklus. Pelaksanaan tindakan dalam penelitian ini melibatkan guru kelas IV sebagai observer aktivitas guru (peneliti) dan teman sejawat sebagai observer aktivitas siswa dan membantu dalam mendokumentasikan pembelajaran.

\section{Siklus I}

Pelaksanaan Penelitian Tindakan Kelas siklus 1 dilaksanakan pada hari Rabu dan Kamis, tanggal 30 Oktober 2013 dan 31 Oktober 2013 dengan alokasi waktu tiap pertemuan 2 x 35 menit. Subjek penelitian 18 siswa kelas IV semester 1 tahun ajaran 2013/2014. Siklus I dilaksanakan berdasarkan RPP yang telah disetujui oleh guru kelas IV dan diketahui Kepala SD 2 Bacin Kudus. Pelaksanaan tindakan siklus I tertuju pada materi pengertian, jenis-jenis, contoh dan persebaran Sumber Daya Alam dengan menggunakan model Contextual Teaching and Learning.

Aktivitas pembelajaran guru pada siklus I guru masih belum segan dalam menegur siswa yang nakal atau jahil, sehingga siswa meremehkan guru tersebut. Hal tersebut mengakibatkan siswa cenderung ramai, berbicara dengan temannya sendiri saat proses pembelajaran. Guru belum dapat menumbuhkan keberanian dan percaya diri siswa saat presentasi dan mengajukan pertanyaan.

Hasil belajar pada siklus I berupa kemampuan menemukan jenis-jenis dan persebaran Sumber Daya Alam melalui pengamatan dan diskusi kelompok dengan rata-rata nilai kelas 71,9 artinya sudah melebihi batas KKM. Persentase tersebut telah sesuai dengan kriteria ketuntasan yang ingin dicapai dalam pembelajaran IPS, sehingga dapat dinyatakan berhasil.

Pada saat melakukan pengamatan aktivitas belajar siswa dengan menerapkan model CTL materi Sumber Daya Alam peneliti menggunakan lembar observasi aktivitas belajar IPS siswa. Pada siklus1 siswa masih merasa canggung dan malu saat proses pembelajaran. Siswa menyontek pekerjaan temannya saat tes akhir siklus I berlangsung. Saat melakukan pengamatan kegiatan diskusi kelompok siswa masih belum terbiasa berkelompok. Siswa juga masih belum aktif, masih terkesan malu dan belum berani secara keseluruhan mengeluarkan ide, pendapat dan gagasannya kepada teman sekelompok. Pada saat melakukan presentasi, siswa masih merasa malu berdiri di depan kelas. Dari paparan di atas, maka peneliti perlu melakukan penelitian siklus II, agar pembelajaran yang dikelola 
guru dan hasil belajar pada siklus I dapat meningkat lebih baik.

\section{Siklus II}

Pelaksanaan tindakan pertemuan siklus II dilaksanakan sesuai dengan jadwal pelajaran IPS. Siklus II dilaksanakan dengan $2 \mathrm{x}$ pertemuan, yakni pada tanggal 7 dan 14 November 2013. Pengelolaan pembelajaran guru siklus II memperoleh hasil diantaranya guru sudah dapat menguasai kelas dengan baik, menumbuhkan semangat dan motivasi siswa dalam proses pembelajaran. Guru sudah berani menegur siswa yang nakal atau jahil, merespon pertanyaan siswa dengan baik.

Hasil belajar pada siklus II berupa kemampuan menemukan pemanfaatan dan cara pelestarian Sumber Daya Alam melalui pengamatan dan diskusi kelompok dengan rata-rata nilai kelas 82,5 artinya sudah melebihi batas KKM. Persentase tersebut telah sesuai dengan kriteria ketuntasan yang ingin dicapai dalam pembelajaran IPS, sehingga dapat dinyatakan berhasil.

Hasil observasi aktivitas belajar IPS siswa secara individu pada siklus II yaitu pada pertemuan ke-1 siklus II ini, siswa terlihat tenang saat kegiatan pendahuluan. Pada pertemuan ke-2 ada sebagian siswa yang berani bertanya kepada guru tentang materi yang sedang diajarkan. Kemudian siswa mengerjakan tes akhir siklus II dengan antusias dan tenang. Siswa sangat senang dengan model CTL.
Siklus II pertemuan 1 ini siswa cukup antusias dalam mengerjakan LKS dalam kelompok. Saat siswa melakukan presentasi hasil diskusi banyak siswa dapat menjawab dengan tepat. Kekompakan kelompok lebih terlihat dibandingkan pertemuan sebelumnya. Siswa sudah terbiasa belajar secara berkelompok. Selesai mengerjakan, siswa melakukan presentasi dengan semangat dan percaya diri. Pada pertemuan ke-2 siswa langsung mengelompok sesuai dengan kelompoknya untuk memulai diskusi dari LKS yang dibagikan guru. Guru membimbing dan memotivasi siswa agar dapat aktif dalam diskusi kelompok. Hasilnya siswa sangat antusias dalam mengerjakan LKS, dan berani mendemonstrasikan temuannya.

Penerapan model Contextual Teaching and Learning (CTL) pada materi Sumber Daya Alam dapat meningkatkan hasil belajar IPS siswa kelas IV semester 1 SD 2 Bacin Kudus Kecamatan Bae Kabupaten Kudus tahun ajaran 2013/2014, sehingga peneliti tidak perlu melanjutkan siklus berikutnya.

\section{PEMBAHASAN}

Pengelolaan pembelajaran IPS menggunakan model Contextual Teaching and Learning (CTL) mengalami peningkatan. Hal tersebut ditunjukkan dengan aktivitas pembelajaran yang dilakukan oleh guru yang berjalan dengan lancar. Hasil observasi aktivitas peneliti pada siklus I yaitu 71,5 dengan persentase $71,5 \%$ atau pengelolaan pembelajaran IPS dikategorikan baik. Pada siklus II pelaksanaan 
pembelajaran mengalami peningkatan dari siklus I, kedaan ini terlihat skor rata-rata pada setiap pertemuan yang meningkat mencapai skor 92,5 dengan persentase 92,5\% atau pengelolaan pembelajaran IPS dengan penerapan model Contextual Teaching and Learning (CTL) dikategorikan sangat baik.

Pengelolaan pembelajaran guru telah berjalan dengan baikm, guru mampu mengaitkan materi yang di ajarkan dengan dunia nyata siswa. Dalam mengaitkan materi pelajaran dengan dunia nyata, guru menerapkan 7 komponen CTL. Hal ini sesuai dengan pendapat Nurhadi, dkk (2004: 31) ada tujuh komponen utama pembelajaran yang mendasari penerapan pembelajaran kontekstual di kelas. Ketujuh komponen utama itu adalah konstruktivisme (Constructivism), bertanya (Questioning), menemukan (inquiry), masyarakat belajar (Lerning Community), pemodelan (Modeling), refleksi (Reflection), dan penilaian sebenarnya (Authentic Assessment).

Peningkatan pada siklus II terjadi karena lebih dapat mengelola kelas dan waktu sehingga pembelajaran IPS pada siklus II lebih efektif dari siklus I. Peningkatan aktivitas guru dalam mengelola pembelajaran menggunakan model Contextual Teaching and Learning (CTL) dapat dilihat pada diagram di bawah ini.

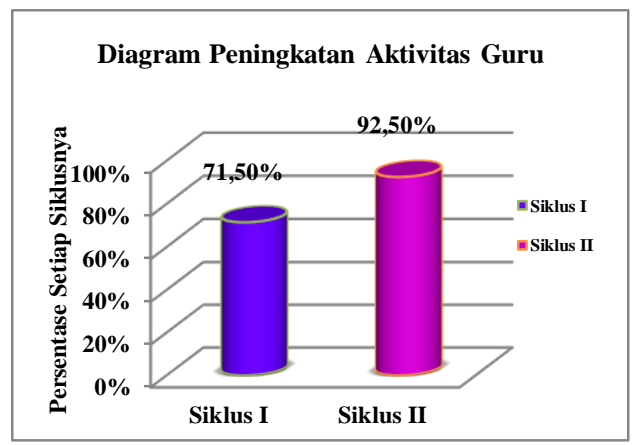

Diagram Hasil Peningkatan Aktivitas Guru dari Siklus I Sampai Siklus II.

(Sumber: Data Primer, 14 November 2013)

Hasil belajar siklus I yang mencapai nilai rata-rata klasikal 71,9 dengan nilai tertinggi 90 dan nilai terendah 40. Dari 18 siswa kelas IV SD 2 Bacin Kudus, 13 siswa telah mencapai KKM dan 5 siswa belum mencapai KKM dengan pencapaian ketuntasan persentase $72,22 \%$.

Pada siklus II nilai rata-rata kelas yang diperoleh yaitu mencapai 82,5 . Sebanyak 17 siswa telah mencapai ketuntasan hasil belajar dan hanya 1 siswa yang belum tuntas. Dari 18 siswa nilai tertinggi yang dicapai sebesar 100 dan nilai terendah 60. Adapun jumlah persentase ketuntasan yaitu $94,44 \%$ dan jumlah persentase ketidak tuntasan $5,56 \%$.

Hal ini sesuai tuntutan sebagaimana yang disampaikan oleh Purwanto (2011: 44) hasil belajar 
ialah hasil yang menunjuk pada suatu perolehan akibat dilakukannya suatu aktivitas atau proses yang mengakibatkan berubahnya input secara fungsional. Belajar dilakukan untuk mengusahakan adanya perubahan perilaku pada individu yang belajar. Perubahan perilaku itu merupakan perolehan yang menjadi hasil belajar. Pengertian tersebut menjelaskan bahwa hasil belajar merupakan perubahan tingkah laku dengan melakukan suatu aktivitas sebagai usaha belajar yang lebih baik dari sebelumnya.

Hasil yang diperoleh dari siklus I dan siklus II terjadi peningkatan ketuntasan hasil belajar secara klasikal ini dapat dilihat pada diagram berikut.

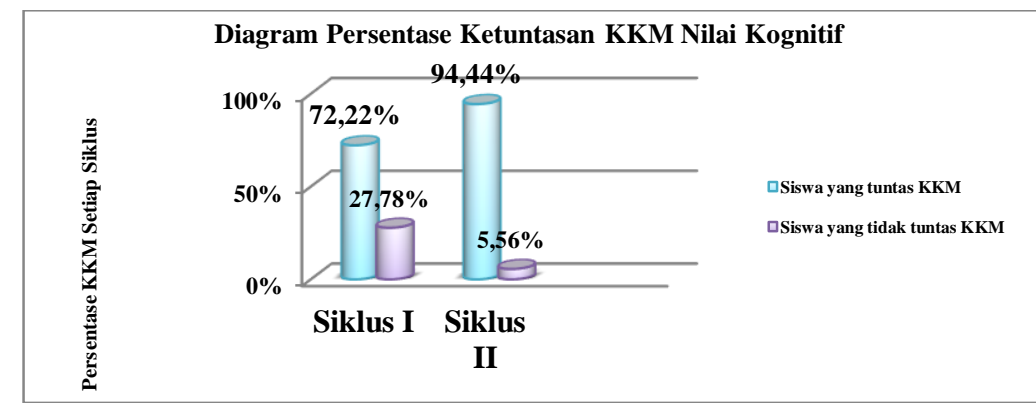

Diagram Hasil Peningkatan Hasil Belajar IPS Aspek Kognitif Siswa dari Prasiklus, Siklus I Sampai Siklus II.

(Sumber: Data Primer, 14 November 2013)

Hasil belajar siswa aspek afektif baik secara individu maupun berkelompok pada pembelajaran IPS materi Sumber Daya Alam melalui model Contextual Teaching and Learning (CTL) dari kedua pertemuan di siklus I menunjukkan hasil belajar aspek afektif secara individu total skor rata-rata 52,5 dengan persentase $72,93 \%$ termasuk dalam kategori baik. Pada siklus II menunjukkan rata-rata untuk semua indikator yang dikembangkan meningkat dengan skor rata-rata 61,5 dan persentase mencapai $85,38 \%$ termasuk dalam kategori sangat baik.

Hasil belajar aspek afektif secara kelompok pada siklus I menunjukkan total skor rata-rata 34 dengan persentase $70,83 \%$ termasuk dalam kategori baik. pada siklus II juga mengalami peningkatan, hal ini ditunjukkan dengan total skor ratarata 41 dan persentase mencapai $85,43 \%$ termasuk dalam kategori sangat baik.

Hasil belajar aspek psikomotorik skor rata-rata yaitu 34,4 dengan persentase $71,5 \%$ termasuk dalam kategori Baik. Pada siklus II skor rata-rata mencapai 41,4 dengan persentase $86,1 \%$ atau termasuk dalam kategori sangat baik, sehingga dapat dikatakan penerapan model pembelajaranCTL aspek psikomotorik dalam pembelajaran IPS pada kelas IV SD 2 Bacin Kudus berjalan dengan efektif.

Secara keseluruhan pembelajaran yang dilakukan pada siklus II telah mengalami 
peningkatan pada aspek psikomotorik. Hal diperkuat dengan penelitian yang dilakukan oleh Yaningsih (2010) dalam meningkatkan motivasi belajar siswa dengan menerapkan model CTL. Berdasarkan penelitian tersebut maka dapat disimpulkan bahwa penerapan model CTL dapat meningkatkan aktivitas belajar siswa aspek psikomotorik pada pembelajaran IPS.

Berdasarkan hasil penelitian yang telah dijelaskan di atas, maka dapat disimpulkan bahwa hipotesis menyatakan bahwa "Model Contextual Teaching and Learning dapat meningkatkan Hasil Belajar IPS Siswa Kelas IV SD 2 Bacin Kudus Materi Sumber Daya Alam Tahun Ajaran 2013/2014" diterima karena teruji kebenarannya.

\section{SIMPULAN}

Penerapan model Contextual Teaching and Learning (CTL) pada siswa kelas IV SD 2 Bacin Kudus, maka peneliti menarik kesimpulan bahwa penerapan model CTL pada materi Sumber Daya Alam dapat meningkatkan hasil belajar siswa siswa kelas IV SD 2 Bacin Kudus materi Sumber Daya Alam tahun ajaran 2013/2014. Hal ini dikarenakan dalam model CTL, materi yang dipelajari siswa dihubungkan dengan kehidupan nyata atau kehidupan sehari-hari siswa, sehingga akan memperjelas materi yang disajikan oleh guru dan akhirnya dapat meningkatkan hasil belajar pada materi Sumber Daya Alam.
Saran dalam penelitian ini guru diharapkan menjadikan model Contextual Teaching and Learning (CTL) sebagai referensi dalam memilih model pembelajaran. Hal ini dikarenakan model CTL merupakan salah satu alternatif model pembelajaranyang dapat menjadikan siswa aktif, kreatif, menyenangkan dan pembelajaran pun menjadi bermakna.

\section{DAFTAR PUSTAKA}

Akbar, Sa'adun. 2010.

Pengembangan Kurikulum dan Pembelajaran Ilmu Pengetahuan (IPS). Yogyakarta: Cipta Media.

Aqib, Zaenal. 2009. Penelitian Tindakan Kelas. Bandung: Yrama Widya.

Arikunto, Suharsimi. 2009. Penelitian Tindakan Kelas. Jakarta: Bumi Aksara.

Arikunto, Suharsimi. 2010. Prosedur Penelitian Suatu

Pendekatan Praktik. Jakarta: Rineka Cipta.

Asmani, Jamal Ma'mur. (2011a). Tips Pintar PTK1 Penelitian Tindakan Kelas. Yogyakarta: Laksana.

Asmani, Jamal Ma'mur. (2011b).

$\begin{array}{lr}\text { Tuntunan } & \text { Lengkap } \\ \text { Metodologi } & \text { Praktis } \\ \text { Penelitian } & \text { Pendidikan. } \\ \text { Yogyakarta: Diva Press. }\end{array}$


Asrori, Mohammad. 2009. Penelitian Tindakan Kelas. Bandung: CV Wacana Prima.

Bosko, Rafael Edy. 2006. Hak-Hak Masyarakat Adat dalam Konteks Pengelolaan Sumber Daya Alam. Jakarta: Elsam.

Daryanto. 2012. Model pembelajaranInovatif. Yogyakarta: Gava Media

Dimyati dan Mudjiono. 2006. Belajar dan Pembelajaran. Jakarta: Rineka Cipta.

Djamarah, Syaiful Bahri. 2011. Psikologi Belajar Edisi II. Jakarta: Rineka Cipta.

Faridah, Anik. 2010. Upaya Peningkatan Prestasi Belajar Siswa kelas IV MI Salafiyah Kendal Kecamatan Boyolali Tahun Ajaran 2010/2011. Tersedia di http://jurnal.dikti.go.id. Diunduh pada 28 Juli 2013.

Gunawan, Rudy. 2011. Pendidikan IPS Filosofi, Konsep dan Aplikasi. Bandung:

Alfabeta.

Hamalik, Oemar. 2012. Proses Belajar Mengajar. Jakarta: Bumi Aksara.

Komalasari, Kokom. 2011. Pembelajaran Kontekstual. Bandung: Refika Aditama.
Nurhadi, dkk. 2004. Pembelajaran Kontekstual (Contextual Teaching and Learning/CTL) dan Penerapannya dalam KBK. Malang: Universitas Negeri Malang (UM Press).

Permendiknas Nomor 22 Tahun 2006 tentang Standar Isi Mata Pelajaran IPS. 2006. Jakarta: Diperbanyak oleh Absolut.

Purwanto. 2011. Evaluasi Hasil Belajar. Yogyakarta: Pustaka Pelajar.

Ratnaningsih, Maria, dkk. 2004. Proceeding Natural Resources and Environmental Accounding. Yogyakarta: BPFEYogyakarta.

Reksohadiprodjo, Sukanto. 2009. Ekonomi Sumber Daya Alam dan Energi Edisi 2. Yogyakarta: BPFEYogyakarta.

Riyanto. 2010. Paradigma Baru Pembelajaran sebagai Referensi bagi Pendidik dalam Implementasi Pembelajaran yang Efektif dan Berkualitas. Jakarta: Kencana Prenada Media Group.

Rusman. 2012. Model-model pembelajaranMengembangk 
an Profesionalisme Guru. Jakarta: PT RajaGrafindo Persada.

Sanjaya, Wina. 2012. Penelitian Tindakan Kelas. Jakarta: Kencana Prenada media Group

Sapriya. 2009. Pendidikan IPS. Bandung: PT Remaja Rosdakarya.

Setyosari, Punaji. 2012. Metode Penelitian Pendidikan dan Pengembangannya. Jakarta: Kencana Prenada Media Group.

Slameto. 2010. Belajar dan FaktorFaktor yang

Mempengaruhi. Jakarta: Rineka Cipta.

Sudjana, Nana. 2011. Penilaian Hasil Proses Belajar Mengajar. Bandung: PT Remaja Rosdakarya.

Sugiono. 2010. Metode Penelitian Pendidikan. Bandung: Alfabeta.

Sukardi. 2011. Metodologi Penelitian Pendidikan Kompetensi dan Praktiknya. Yogyakarta: Bumi Aksara.

Suparmoko. (2010a). Ekonomi

Sumber Daya Alam dan Lingkungan Edisi 3. Yogyakarta: BPFEYogyakarta.
Suparmoko. (2010b). Ekonomi Sumber Daya Alam dan Lingkungan Edisi 4. Yogyakarta: BPFEYogyakarta.

Surjaningsih. 2010. Meningkatkan Hasil Belajar Siswa Pada Pokok Bahasan

Keanekaragaman

Kenampakan Alam dan Buatan di Indonesia di Kelas V SDN 009 Nunukan Tahun Ajaran 2010/2011. Tersedia di http://garuda.kemdiknas.go.i d. Diunduh pada 1 Agustus 2013.

Syah, Muhibbin. 2012. Psikologi Belajar. Jakarta: PT. RajaGrafindo Persada.

Trianto. 2012. Mendesain Model pembelajaranInovatif Berorientasi

Konstruktivistik. Jakarta: Prestasi Pustaka Publisher.

Undang-Undang Sisdiknas Nomor 20 Tahun 2003. 2004. Jakarta: Diperbanyak oleh Absolut.

Wahab, Abdul Aziz. 2009. Metode dan Model-Model pembelajaranMengajar. Bandung: Alfabeta.

Wiryohandoyo, Soedarno. 1998. Pendidikan Ilmu Sosial. 
Semarang: FPIPS IKIP

Semarang.

Yaningsih, Seti. 2010. Penerapan Pendekatan Kontekstual (Contextual Teaching and Learning) Untuk Meningkatkan Prestasi Belajar IPS Bagi Siswa
Kelas IV SD Negeri 02 Papahan Kecamatan Tasikmadu Kabupaten Karanganyar Semester I Tahun Pelajaran 2009/2010. Tersedia di: http://jurnal.dikti.go.id. Diunduh pada 30 Juli 2013. 